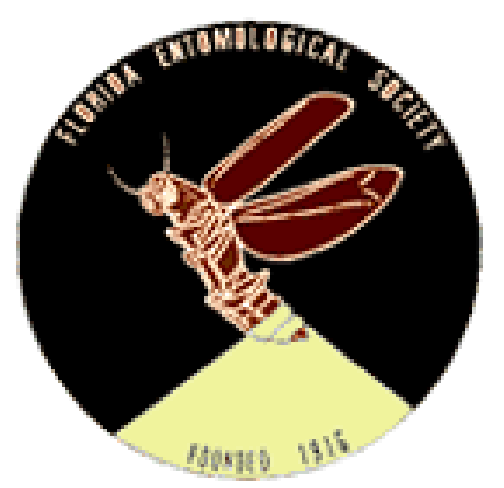

Alternate Orthopteran Hosts (Anurogryllus sp.) of Euphasiopteryx depleta (Diptera: Tachinidae)

Author(s): H. G. Fowler and A. Mesa

Source: The Florida Entomologist, Vol. 70, No. 3 (Sep., 1987), pp. 408-409

Published by: Florida Entomological Society

Stable URL: http://www.jstor.org/stable/3495079

Accessed: $15 / 01 / 2014$ 08:54

Your use of the JSTOR archive indicates your acceptance of the Terms \& Conditions of Use, available at http://www.jstor.org/page/info/about/policies/terms.jsp

JSTOR is a not-for-profit service that helps scholars, researchers, and students discover, use, and build upon a wide range of content in a trusted digital archive. We use information technology and tools to increase productivity and facilitate new forms of scholarship. For more information about JSTOR, please contact support@jstor.org.

Florida Entomological Society is collaborating with JSTOR to digitize, preserve and extend access to The Florida Entomologist. 
SIVINSKI, JOHN. 1978. Intrasexual aggression in the stick insects Diapheromera veliei and D. covilleae and sexual dimorphism in the Phasmatodea. Psyche 85: 395-405.

Sivinskl, JoHN. 1980. The effects of mating on predation in the stick insect Diapheromera veliei Walsh (Phasmatodea: Heteronemiidae). Ann. Entomol. Soc. America 73 (5): 553-556.

\title{
ALTERNATE ORTHOPTERAN HOSTS (ANUROGRYLLUS SP.) OF EUPHASIOPTERYX DEPLETA (DIPTERA: TACHINIDAE)
}

\author{
H. G. Fowler and A. Mesa \\ Instituto de Biociencias \\ Universidade Estadual Paulista, UNESP \\ 13500 Rio Claro, São Paulo, Brazil
}

There is a growing interest in the potential of using the tachinid Euphasiopteryx depleta (Wied.) as a natural enemy for introduction into the U.S. to control mole crickets of the genus Scapteriscus (Orthoptera: Gryllotalpidae). Adult $E$. depleta are attracted to the synthesized calling songs of mole crickets (Fowler \& Kochalka 1985), and can be successfully reared from mole crickets under laboratory conditions (Fowler \& Garcia 1986), as well as from field-collected S. acletus Rehn \& Hebard, S. vicinus Scudder and S. abbreviatus Scudder (Fowler \& Garcia 1987). However, E. depleta can also be captured at synthesized mole cricket calls (Walker 1982), even during those months when adult mole crickets are not calling. This indicates that $E$. depleta must also parasitize other nocturnally active orthopteran species (Fowler \& Garcia 1987).

During the course of our collections and laboratory rearings of gryllids, we have recovered $E$. depleta from a species of Anurogryllus. Four $E$. depleta were obtained from 564 crickets collected in Ipeúna, state of São Paulo, Brazil (26 Feb. 1986, and 15-16 August 1986). Additionally, we have successfully reared $E$. depleta from Anurogryllus sp. after placing larvae under the crickets' pronota. As $E$. depleta has been reared from S. abbreviatus, which does not call, it is possible that song is not a prerequisite for host location. However, we feel confident that the songs of Anurogryllus are attractive to $E$. depleta, based upon preliminary tests with taped Anurogryllus songs in the field.

We have also been able to rear $E$. depleta in the laboratory on nymphs and adults of an undescribed species of Gryllus, using the same techniques. This suggests that laboratory colonies could be maintained on Gryllus for subsequent field release. We have yet to find a field-collected Gryllus (>1,000 assayed) to be parasitized by $E$. depleta. Our collected material is maintained in our private collections.

\section{ACKNOWLEDGEMENTS}

This research was initially funded partially by a grant, USDA 83-CRSR-2-2162. We thank J. H. Frank and T. J. Walker for their interest, and comments on the manuscript. Florida Agric. Exp. Station Journal Series No. 8035. 


\title{
RefERenCes Cited
}

Fowler, H. G., AND C. R. GarCiA. 1987. Attraction to synthesized songs and experimental and natural parasitism of Scapteriscus mole crickets (Orthoptera: Gryllotalpidae) by Euphasiopteryx depleta (Diptera: Tachinidae). Rev. Brasileira Biol. (in press).

$\rightarrow$ Fowler, H. G., AND J. N. KochalKA. 1985. New record of Euphasiopteryx depleta (Diptera: Tachinidae) from Paraguay: attraction to broadcast calls of Scapteriscus acletus (Orthoptera: Gryllotalpidae). Florida Ent. 68: 225-26.

$\rightarrow$ WALKER, T. J. 1982. Sound traps for sampling mole cricket flights (Orthoptera: Gryllotalpidae: Scapteriscus). Florida Ent. 65: 105-10.

\section{FIELD CONFIRMATION OF THE PHONOTAXIS OF EUPHASIOPTERYX DEPLETA (DIPTERA: TACHINIDAE) TO CALLING MALES OF SCAPTERISCUS VICINUS (ORTHOPTERA: GRYLLOTALPIDAE)}

\author{
H. G. FOWLER \\ Instituto de Biociencias \\ Universidade Estadual Paulista, UNESP \\ 13500 Rio Claro, São Paulo, Brazil
}

Euphasiopteryx depleta (Wied.) was reared from an unidentified species of Scapteriscus (Orthoptera: Gryllotalpidae) by Wolcott (1940). In Brazil and Paraguay, $E$. depleta has been attracted to sound traps (Walker 1982) broadcasting the synthesized songs of S. vicinus Scudder, S. acletus Rehn \& Hebard, and S. imitatus Nickle \& Castner (Fowler \& Garcia 1986, Fowler \& Kochalka 1985). As species of Scapteriscus are exotic pests in the U.S., accidentally introduced from southern South America (Nickle \& Castner 1984), the attraction of the Neotropical $E$. depleta to synthesized broadcast calls of Scapteriscus makes it a candidate for introduction in a biological control program for species of Scapteriscus.

Although we have reared $E$. depleta from field-collected $S$. vicinus Scudder in the state of São Paulo, Brazil (Fowler \& Garcia 1986), and Wolcott (1940) reared it from field-collected Scapteriscus sp. in the state of Pará, Brazil, its low incidence adds some doubt as to its potential as a biological control agent. However, E. depleta can be attracted in large numbers to broadcast synthesized songs of Scapteriscus spp. (Fowler $\&$ Garcia 1986), which suggests this phonotactically orienting parasitoid could respond numerically to mole cricket density. Although mole crickets of the genus Scapteriscus are univoltine in the state of São Paulo, with male $S$. vicinus calling from September through January, $E$. depleta can be attracted to sound traps practically all year. This suggests that species of Scapteriscus are not the only orthopteran hosts of $E$. depleta, or that $E$. depleta is not a normal parasitoid of species of Scapteriscus and that the attraction of large numbers of female $E$. depleta to sound traps might be a physiological quirk. This would also explain its low incidence $(<1 \%)$ in field-collected mole crickets.

To test if $E$. depleta females are attracted to calling $S$. vicinus males under normal field conditions and not to the super-stimulus of a sound trap, I marked calling $S$. vicinus chambers during September 1986, in Rio Claro, São Paulo, Brazil. Because calling chambers of individual S. vicinus males are used for many days (Fowler 1986), 